\title{
State or Private Ownership? A Survey of Empirical Studies
}

\section{Michaela Tichá ${ }^{1}$}

\begin{abstract}
This paper focuses on property rights and performance of enterprises. The objective of this paper is to summarize existing knowledge from empirical studies dealing with the question of whether private property and privatization of enterprises encourage firms to increase their performance measured as growth of profitability, labor productivity, investments, costs effectiveness, etc. On the basis of empirical studies, it is also determined what the influence of institutional frameworks of property rights and privatization is on the firm performance. The first part of the paper reviews results of studies on the non-transition economies privatized by 1990 . The second one evaluates the impact of private ownership on performance of enterprises from transition economies of Central and Eastern Europe, and the Former Soviet Union. The results of the studies suggest that private ownership is an important but not sufficient determinant of firm prosperity, subsequently resulting in overall rise of wealth of nations. The positive impact of private ownership on economic performance can occur only in an appropriate institutional environment with relevant legal standards (righteous and enforceable contracts, the protection of shareholders and creditors, adequate banking system, functioning bankruptcy courts, capital market supervision, etc.).
\end{abstract}

Key words: Economic performance, Institutional environment, Private ownership, Privatization, State-owned enterprises

JEL Classification: L33, P31

\section{Introduction}

Economists have been searching for factors contributing to prosperity of countries for a long time. They usually focus their attention on efficient use of classic production factors such as natural resources, labor and capital. The famous neo-classical growth theory, based on neoclassical production function, includes these traditional production factors (labor force and capital per worker) in its model and adds exogenous technological progress which shifts frontier of steady state. Therefore, it allows further economic growth of a country. New growth theory holds that economic growth is mainly the result of endogenous forces containing human capital, innovation and knowledge, without diminishing marginal returns. Nevertheless, primarily according to empirical research, it seems that there are other factors that to some extent explain the differing economic levels of countries. The neo-classical principles are partly modified

\footnotetext{
${ }^{1}$ VŠB-Technická univerzita Ostrava, Ekonomická fakulta, Sokolská tř. 33, 70121 Ostrava 1, email: michaela.ticha@vsb.cz
} 
and enlarged by institutional economic thinking that offers a theoretical framework for connection of the economic and institutional environment where economic agents make their decision and firms operate.

Representatives of the new institutional economics increasingly include institutions ${ }^{2}$ among the factors affecting economic prosperity of a country and its firms. Potential of a country is usually not fully developed and often remains untapped without a quality institutional environment, including good formal and informal law institutions (e. g. Olson 1996, 2000; Soto 2000 etc.) that contain, among others, ownership institution which includes observance and enforcement of property rights. According to North and his path dependence point of view, current conditions for use of resources in an economy depend not only on the current written standards (formal rules), but also on the historical formation of property rights, informal, never formally written customs and habits, which are legally unenforceable but they largely affect behavior and decision of economic agents (North 1990). Individual countries' approaches to ownership vary according to different factors, including their historical experience. While inviolability of private property has been taken for granted in some countries for hundreds of years, other countries have saved different models of ownership in their historical memory, and this is reflected in the current approach to property rights, including their protection and compliance.

Economists widely agree with the opinion that allocation of ownership among agents is essential in the world of scarce resources (Furubotn and Richter 2005). Kouba (2005) claims that efficient allocation of production factors is conditioned by well-defined property rights that have to be divisible, transferable and enforceable. But opinions differ on whether private property should prevail, or vice versa state ownership would be better. These differences in opinions between defenders of private property and state ownership do not cease in spite of the recent collapse of socialist systems of centrally planned economies. Moreover, many economists study this dispute in a broader context concerning environmental, migration, and economic policy issues or military conflicts associated with the protection or conquest of property.

Relationship between character of ownership and economic prosperity is the topic of a large number of treatises both in country perspective (on macroeconomic level) and on an enterprise level (microeconomic approach). This paper focuses on property rights and performance of enterprises.

The objective of this paper is to summarize the existing knowledge from empirical studies which deal with the question of whether private property and privatization of enterprises encourage firms to increase their performance. On the basis of empirical studies, we will try to examine whether results of the studies vary, depending on the type of analyzed countries and on their other institutional conditions.

\footnotetext{
${ }^{2}$ Institutions consist of formal rules, informal constraints (norms of behavior, conventions, and self-imposed codes of conduct) and enforcement characteristics of both. Institutions affect economic performance by determining (together with the technology employed) transaction and transformation (production) costs. If institutions are the rules of the game, organizations are the players (North 1990).
} 
The paper is organized as follows: The first section offers a theoretical background of empirical studies, including their assumptions. Most commonly used methodology is presented in the second part of this paper. The next section summarizes empirical studies and their results. This chapter is divided into two parts: first of all, we discuss effects of privatization and ownership on firm performance in non-socialist countries till the nineties, and in the second part the effect of privatization in transition postcommunist economies since the early nineties (separately Central and Eastern Europe, and States of the Former Soviet Union) is scrutinized. The conclusion summarizes the results of the studies.

\section{Empirical Studies: Property Rights and Performance in Theoretical Perspective}

Most empirical studies are based on the assumption that clearly defined property rights decrease transaction costs for firms and limit activities towards short-run returns without large-scale investments to physical and human capital. Based on Roman law, property is mostly seen as the legal right of possession and use (usus), the right to use and derive profit or benefit from property (usus fructus), and the right to transfer or sell the property (abusus) (Klusoň 2004). Freely transferable property rights and their protection is essential for a market economy - poor enforcement, high transaction costs of contract observance, and unpredictability of legal environment complicate both the running of domestic firms and the entry of foreign investors. Property rights are the base of efficient market mechanisms only if they meet not only basic attributes (usus, usus fructus, and abusus), but also other characteristics, for example property exclusivity which means the right to exclude others from the property. Interference with property rights is possible only on the basis of legal standards and the state must protect them through its power on the principle of enforceability of property rights.

Theoretical base of empirical studies mostly emphasizes the positive impact of private property on economic prosperity. In the environment of private property there is an efficient use of scarce resources which results in increasing productivity and prosperity. Mercuro and Medema (2006) underline the importance of property rights in economic analysis and in determining economic performance on two facets. First, property rights structure the incentives that determine economic behavior and performance. Second, "property rights significantly influence the distribution of wealth and power within an economic system. Different property rights structures thus give rise to differential opportunity sets and thus, different allocations of benefits and costs among economic agents, and thereby affect economic choices through their respective structures of incentives and constrains" (Mercuro and Medema 2006, p. 249).

Furubotn and Richter (2005) claim that the stimulatory effect of private property helps to save transaction costs and so it contributes to the economic performance of firms and welfare of the whole society. Transaction costs are an important part of new institutional economics thanks to R. H. Coase who uses them to explain existence of firm and solution of externalities. Transaction costs include costs of searching for business partners, obtaining information on market prices, cost of price negotiations, contract enforcement, etc. In the case of low transaction cost, firms can operate effectively.

Another part of the theoretical discussion on property rights and firm performance refers to product-market competition. Some of economists argue that both public and private 
ownership are good in competitive markets. However, Frydman et al. (1993) declare that state-owned firms are inefficient even when they operate in a competitive market environment because competition cannot replace the effect of private property. It is clear that in the case of poor governance in the public sector high level of corruption and low incentives to effectively manage, it is probable that state-owned firms will perform poorly due to the fact that decision-makers in these firms pursue their own interest which is affected by mostly temporary work in the company. So that in competitive markets, we can consider that private owner with longstanding relationship to the firm will not seek a short-term benefit but prefer stable and long-term prosperity of the firm by investing in human capital, innovation and technological progress that are needed for successful position in competitive market.

The problem of current big private corporations is that modern firms separate the functions of ownership and control, famous as principal-agent problem or theory of agency. Certainly, problems of separation of ownership and control regard to both private and state-owned firms, moreover, some of economists (e.g. Chang and Singh, 1997) argue that this fact alone eliminates the differences between state and private ownership. However, their arguments ignore the mainstream theoretical framework of corporate governance that underlines differences between state and private governance and its impact on firm performance. Shirley and Walsh (2000) mention differences between the state and the private in the context of the major methods of governance: monitoring by owners and formal legal restraints. Although monitoring depends largely on the type of owners and on information asymmetries, it is clear that state and private owners monitor differently. One approach underlines advantage of concentrated ownership in state firms leading to more effective monitoring; the second one highlights the ability of markets to generate information, which gives private ownership a crucial advantage in the monitoring process. Formal legal protection of owners who conclude contract with managers is another method of controlling managers. The state ownership is not sufficient for such enforceable contracts due to political interferences and failure of governments to fulfill their obligations.

Intensity of t property rights protection is another topic discussed in the theoretical parts of studies. Economists usually agree with the opinion that protection of property rights and low risk of expropriation strengthen motivation of investors because it increases legal certainty for companies. ${ }^{3}$ In the case of the formerly centrally planned economies of the socialist block, there was expropriation of production factors as limiting constrains for economic prosperity which resulted in lack of motivation and responsibility for effective management. Property institution in socialist countries, namely private property, lacked the basic attributes of Roman law (usus, usus fructus, abusus). Although private property was sometimes defined de jure, owners could not apply their property rights de facto; for example, they could not fully dispose of their

\footnotetext{
${ }^{3}$ Chang (2007) objects to the sometimes uncritical view that the stronger protection of property rights, the better. Immoderate protection of property rights can result in some potential sources remaining untapped. Particularly in developing countries, too strong a protection of patents and other intellectual property can increase costs of their application for firms. As an example, Heitger (2004) states Chinese companies where a weak protection of property rights (especially intellectual property) outright contributes to their faster economic growth. Companies holding patents certainly have a different opinion on the matter.
} 
property, use benefits freely, etc. On the other hand, if the private owners can rely on the institutional system to protect their property, and also preclude some non-standard procedures, they probably strive for the management strategy which is beneficial for economic performance of companies in the long term. According to Havrylyshyn and McGettigan (1999), private owners have a greater incentive to efficient management because they are financially responsible for their action. On the contrary, managers of state-owned enterprises are often selected for reasons other than their ability to effectively manage a company. These reasons are frequently ideological attitudes, political contacts and lobbying, whilst managers of private firms are generally selected according to their management skills.

To conclude this section, a note that most studies provide theoretical arguments in favor of privatization of formerly state-owned firms based on the premise that privatization is a response to the failing of state ownership that has harmful effects on economic performance. This assertion is based on neo-classical assumptions of perfect competition and information, no externalities in production and consumption, and no public good without any influences of the overall institutional environment, including the political and legal rules of the game.

\section{Methodology of Empirical Studies}

Studies that deal with property structure of companies and their performance evaluate either the performance of the enterprises before and after their privatization (changes over time), or studies comparing performance of state-owned to private firms during the same period. These studies are sometimes focused on one specific industry (airlines, financial sector, network industries: energy, telecommunications, railways, etc.) Based on direct surveys in enterprises, or using publicly available data, the authors examine the influence of ownership structure and privatization on firm performance. The impact of private ownership on employment in firms, investment rate, or production structure is another focus of interest.

There are generally two possibilities of how to analyze the relationship between the ownership and firm performance:

1. Comparison of pre- and post-privatization performance of selected privatized firms. Studies concentrate on individual countries, specific owners, or particular conditions, and capture changes of performance of the same enterprises before privatization and during several years after privatization. Frydman et al. (1999) point to the fact that although this historical approach looks impressive at first sight, it can suffer from some distortion resulting from, for example, the mutual causality. Pre- and post-privatization comparison is more significant if it includes used privatization programs that are accompanied by stricter financial discipline and reduction of state support. As a result, to separate the impact of new ownership structure from the impact of the new firm policy is difficult or downright impossible. Moreover, traditional privatization often requires important financial injections and it is usually preceded by intensive preparation connected with reorganization of management and organization structure. The impact of the preprivatization preparations can cause some post-privatization improvement and misrepresents the impact of ownership change on firm performance. This first 
method is used for example by Megginson, Nash, Randenborgh (1994) who examine privatization changes of firms in the period 1960-1990.

2. Comparison of state-owned firms to private firms operating under comparable conditions, usually within the same or similar industries: at the same time, on the same market, and in similar institutional environments. This approach also has its difficulties. To extract a clear impact of the ownership, a study has to eliminate some distortions that occur when for example more efficient firms are selected for privatization, and the less successful remain in state hands. So a solution for analyzing whether private firms perform better than the state-owned ones is already determined in advance. We can see this approach in the paper of Boardman and Vining (1989) who compare performance of 500 of the biggest non-US industrial corporations, both private and state-owned.

According to Frydman et al. (1999), it is best to choose a combination of both approaches: the comparison of private and public companies at the same time under similar conditions, but also the analysis of their historical data, the course of privatization, etc.

Microeconomic studies examining the relationship between property structure and firm performance usually use statistical methods such as correlation and regression analysis, where the dependent variable is performance of the firm (the level or changes over time) which is measured as the rate of return, profit rate, size of turnover, labor productivity (e.g. net sales per employee), etc. Independent variables contain the type of ownership, rate of privatization, privatization method, etc.

In comparison with macroeconomic studies on the economic performance that almost uniformly use neo-classical production functions with small variations in the variables, microeconomic studies on the enterprise-level use estimating equations with more different variables. A typical equation takes the following form (Earle 1998, p. 17):

$S L_{i}=\alpha+\beta O W N_{i}+\delta S L_{i}(-4)+\gamma \operatorname{Re}$ gion $_{i}+\eta$ Industry $_{i}+\varphi$ Size $_{i}+\varepsilon_{i}$,

where the dependent variable $S L_{i}$ is defined as the natural logarithm of the ratio of sales $(S)$ to employment $(L)$ in year $i$ (in this case in the year 1994). $O W N$ is a specification of the different types of owners; $S L_{i}(-4)$ denotes variable in the year 1990, and $\varepsilon_{i}$ is an unobserved residual. Controls are region (three regional categories), industry (seven industry categories), and size (three size group). Variables capturing the conditions under which the enterprises operate can include not only industry or size group, but degree of competitiveness, quality of management, the ability of managers to attract funds (e.g. Grygorenko and Lutz 2004), character of inputs (labor, material, energy), or bank financing (Pohl et al. 1997), too.

\section{Ownership and Enterprise Performance: Empirical Evidence}

First studies on ownership and performance of a firm originated in the United States as early as the 1930s. Further empirical papers deal with the period 1960-1990, when the privatization programs were conducted both in developed countries and developing countries (e.g. in Chile and Mexico). Nevertheless, we can find studies dealing with type of property and economic performance of companies from the deeper past. 
One of them illustrates a typical question of whether state-founded or private projects are more efficient. The study focuses on the performance of private vs. state-funded expeditions to North Pole and other significant discoveries in the Arctic regions in the period 1818-1909. Using multiple regression analysis, Karpoff $(2001)^{4}$ concludes that state-funded expeditions were much less efficient than the privately funded ones, which achieved more important research goals with lower costs. Compared with privatefunded expeditions, their state-funded counterparts were not so successful although they were better funded. They faced not only substantially higher costs connected with the organization of expeditions, but also higher overall losses in equipment (including ships) and lives: they reported a higher average death rate of crew members and incidence of scurvy. Using an econometric model, Karpoff proves that these differences are not caused by differences in the research goals, in the location, the experience of expedition leaders, level of risk, or in different time of expedition but it is caused by whether expeditions were funded by the state or the private sector. The author explains that state-funded expeditions were notably inefficient because they were poorly organized and executed relative to private expeditions. Despite the greater amount of money and ships for the expedition, the leaders were poorly motivated to expend funds efficiently and reasonably, they adapted slowly to important innovations regarding equipment and nutrition on the expeditions, and their crew members were not prepared well.

Actually, a large group of studies arises with post-communist transformation in the 1990s: the first studies are concerned with firm performance after the so-called small privatization, and further studies deal with the situation after large-scale privatization. For comparison, the privatization before the transformation (the period 1980-1991) was related to 6,800 middle and large companies in the world. The privatization in the transition economies (after 1989) is unprecedented in its scope: more than 60,000 middle and large enterprises were privatized in less than a decade. The privatization of small firms is estimated at thousands of cases (Havrylyshyn and McGettigan 1999).

The following section evaluates the results of the studies on the ownership and enterprise performance in the following group of countries:

- Empirical studies on the non-transition economies;

- Empirical studies on the transition economies: Central and Eastern Europe, and the Former Soviet Union, separately.

\subsection{Empirical Studies on the Non-Transition Economies}

The scope of the nationalization of productive resources and their subsequent privatization have become indisputably the largest in size in the former socialist countries, but - at least partly and under different political and other conditions - the transfer of private property into the hands of the state also concerned firms outside the socialist bloc. The Great Depression in the 1930s, the Second World War, and the disintegration of the colonial system prompted Western governments to the interventionist policy, including control over the banking sector and some of the

\footnotetext{
${ }^{4}$ J. M. Karpoff received the prestigious econometric award Griliches Prize in Empirical Economics for this study in 2003.
} 
industrial enterprises in key sectors that were included in the nationalization programs. In the spirit of renewal of economy torn by the war, Western Europe nationalized particularly strategic sectors such as energy, telecommunications, railways, airlines, etc.

We can find a long tradition of state interventionism with elements of centralism, economic nationalism and shift to state ownership in France which nationalized some key industries (including car factories) after World War II. At the same time, Great Britain was undergoing an extensive nationalization of strategic sectors, too, so in the mid-seventies, state-owned companies had 11\% share of GDP and employed nearly 2 million workers (Cook, 1998). In the late seventies and early eighties, a privatization program was launched that was initiated by Margaret Thatcher, the British Prime Minister, who used the expression privatization in practice for the first time, instead of the previous term denationalization (Megginson, and Netter, 2003). The goal of the privatization was to streamline companies, to support consumer freedom, liberalization of public monopolies, development of financial markets, and to promote broad ownership shares in British households. The shares were offered to employees at a discounted price; this phenomenon was called a property-owning democracy. ${ }^{5}$

Similar developments can be seen in other Western countries, too. The state had a strong presence in Italian and Spanish companies but state enterprises were inefficient, wasting resources, and therefore, Italy and Spain also joined the privatization in the 1980s. Situation relating to the ownership of German enterprises was specific due to military policy in the thirties and during World War II, when companies were de jure private but property rights were de facto limited and subordinated to arms production. The first privatization programs were launched in the 1960s, and they were picked up on by Kohl in the 1980s. Megginson and Netter (2003) underline process of German reunification in the 1990s, when privatization in the form of restitution or direct sales affected about 8,000 East German companies. In comparison with other post-communist countries, thanks to involvement of West German capital, German privatization took place relatively quickly and with lesser difficulties.

The experience of Western Europe shows that a higher share of state ownership was often associated with authoritarian regimes or with efforts of the state to restore the wartorn economy and rescue ailing firms to maintain employment. Most of this way of solving economic problems through nationalization proved ineffective, as can be seen in the following empirical studies.

From the period 1960-1990, there is the study by Megginson, Nash and Randenborgh (1994) who analyze a sample of 61 firms from different industrial sectors in 18 developing and developed countries. These firms were privatized by a similar method of privatization from 1961 to 1990 . The authors compare number of indicators before and after the privatization: labour productivity (real return to employee, net profit to employee), profitability (return on sales, or assets), capital expenditure to sales, total employment, indebtedness (debt to assets), dividends, etc. Every indicator is a three-

\footnotetext{
${ }^{5}$ Thatcher supported the mass privatization by British households because the natural desire of conservatives was that every family owned a share in the company. It resulted in a large number of shareholders among the inhabitants. Thatcher emphasized this idea in a series of interviews, which was illustrated by these words (Thatcher, 1987): "Our policy is that every earner shall be an owner."
} 
year average of real values before and after the privatization of the company. At the end of the study, the authors declare significant increase in real return, profitability, labour productivity, capital investment spending, and, surprisingly, even total employment. The privatized companies reported significantly lower indebtedness and increase of dividend payout. The firms with more than $50 \%$ change of the original management achieved better results.

Boardman and Vining (1989) examine the economic performance of 500 of the biggest non-US both private and state-owned industrial corporations as of 1983. The firms are divided into three groups according to their ownership: state-owned, private and mixed ownership. The authors conclude that state-owned enterprises and firms with mixed ownership were significantly less profitable and productive than private firms. They also found out that firms with the mixed ownership were not more effective than state ones. It means that only full private ownership generates performance growth. To examine whether profitability, labour intensity and indebtedness had been different in state-owned firms and private ones, Dewenter and Malatesta (2001) chose a similar approach. They tested a sample of 500 of the biggest non-financial international corporations and panel data from three years $(1975,1985,1995)-1,369$ observations in total. Besides the type of ownership, other independent variables were: size of firm, region, industry, and influence of business cycle. The authors concluded that the private companies were significantly more profitable when compared with state-owned ones: the average profitability (profit to return) of private companies was twice the profitability of the state-owned firms. The private firms also had lower rate of indebtedness and higher labour productivity. Actually, state-owned firms tended to employ more workers in comparison to the private firms, they have significantly higher rate of employees per unit of sales. Besides basic analysis, the authors also studied situation of enterprises before and after the privatization both in the short term ( 3 years before and after) and the long term (10 years before and 5 years after the privatization); the results were similar in both cases. Profitability growth was manifested mainly in the first three years after privatization; it was not so robust in subsequent years.

One of the critical views on privatization points at the fact that studies do not present any negative influences of privatization, e.g. how much higher performance is achieved at the expense of employees (layoffs, greater pressure to performance, possibly worse working conditions and lower wages that reduce costs). These concerns are partly rejected, and partly confirmed by the next study (La Porta and López-de-Silanes 1999) which examines 218 Mexican corporations privatized during the period 1983-1991 after the Mexican debt crises in 1982. Controlled firms were often in the red before privatization. The authors conclude that privatized corporations increased profitability relatively quickly (average of 40\%); the increase in profitability is achieved through higher prices $(10 \%)$, by reducing the number of employees $(33 \%)$, and growth of total productivity $(57 \%)$. On the one hand, the number of employees was reduced by almost half. At the same time, on the other hand, wages increased. Furthermore, thanks to significantly higher labor productivity and total performance of the firm, workers had better job prospects for the future.

Boubakri and Cosset (1998) examine the performance of 79 partially or fully privatized firms of different industries in the period 1980-1992. Similarly as in previous studies, the authors confirm the positive impact of privatization on growth of real profitability, 
labor productivity, capital investments, and dividend payout. But they find out that the performance is more considerable in the case of countries with a higher economic level. The same authors (Boubakri and Cosset 2002) examine influence of privatization in African countries where transfer of state enterprises into private hands proceeds at a much slower rate than for example in Latin America or Asia. The authors explain this by saying that successful privatization is obstructed by bad institutional environment with dysfunctional financial market, weak private sector, and limited capital resources. Inadequate regulation and control by the state, asymmetric information, risk aversion, lack of investment incentives, and overall institutional instability do not contribute to effective privatization, nor the growth of the private sector. ${ }^{6}$ Through the examined sample of 16 African companies, Boubakri and Cosset (2002) conclude that we can see higher performance after privatization but, in contrast with previous study (Boubakri and Cosset 1998), this result is not statistically significant (only the growth of capital investment is significant). Moreover, efficiency and real sales slightly decrease (but it is not statistically significant, too). The question is whether the study is credible due to the small sample of firms (16). The authors themselves admit having difficulties in making generalizations based on the results of the study.

The studies we examine in this section are summarized in Table 1. All of them consider how ownership effects firm performance in the non-transition economies till the 1990s. First of all, we can compare pre- and post-privatization performance of the selected enterprises. Most studies on this topic offer strong support for the proposition that postprivatization performance (namely profitability) of enterprises is significantly higher than before the privatization, and it is also accompanied by growth of labor productivity and total productivity of production.

The impact of the privatization on employment is not so straightforward. Based on some studies, we find a reduction of the number of employees while their wages and longterm prospects for further employment arise. According to other papers, we can note that growth of labour productivity and production profitability is accompanied by an increase in number of employees. As described in the studies examined, the privatized enterprises invest more and run less into debt.

Secondly, we can examine studies using another method: a comparison of state-owned firms with private firms operating in the same time. Compared to state-owned firms, private firms seem to be significantly more profitable. We can see better results in enterprises that have changed their previous management, and where the share of state control has been reduced. Finally, we observe that post-privatization performance could depend on the economic level of country. The study analyzing the impact of privatization in Africa (Boubakri and Cosset 2002) denotes that the effect of privatization is conditioned by the overall institutional environment.

\footnotetext{
${ }^{6}$ Soto (2000) points out that the problem of African countries dwells in the lack of formal and protected property that is not written in official documents. This situation results in the fact that property is not transformed into capital.
} 
Table 1: Impact of Type of Ownership on Enterprise Performance: NonTransition Economies

\begin{tabular}{|c|c|c|c|c|}
\hline Authors & Period & Sample & Research goal & Conclusions \\
\hline $\begin{array}{l}\text { Boardman, } \\
\text { Vining } \\
(1989)\end{array}$ & 1983 & $\begin{array}{l}500 \text { of the } \\
\text { biggest } \\
\text { international } \\
\text { firms with } \\
\text { different types } \\
\text { of ownership. }\end{array}$ & $\begin{array}{l}\text { Impact of } \\
\text { ownership } \\
\text { structure on firm } \\
\text { performance } \\
\text { (profitability, } \\
\text { labour } \\
\text { productivity = } \\
\text { LP). }\end{array}$ & $\begin{array}{l}\text { State-owned and mixed } \\
\text { firms are significantly less } \\
\text { profitable, with lower LP } \\
\text { compared with private } \\
\text { firms. Mixed firms are not } \\
\text { more effective than state- } \\
\text { owned firms, only fully } \\
\text { private firms have higher } \\
\text { performance. }\end{array}$ \\
\hline $\begin{array}{l}\text { Megginso } \\
\text { n, Nash, } \\
\text { Randen- } \\
\text { borgh } \\
(1994)\end{array}$ & $\begin{array}{l}1961- \\
1990\end{array}$ & $\begin{array}{l}61 \text { industrial } \\
\text { firms from } 18 \\
\text { developing } \\
\text { and developed } \\
\text { countries. }\end{array}$ & $\begin{array}{l}\text { Firm performance } \\
\text { before and after } \\
\text { the privatization } \\
\text { (measured as } \\
\text { profitability, LP, } \\
\text { debt, return on } \\
\text { investments, } \\
\text { employment). }\end{array}$ & $\begin{array}{l}\text { After the privatization } \\
\text { significant growth of real } \\
\text { returns, profitability, LP, } \\
\text { investments, and even } \\
\text { employment. Further, } \\
\text { significantly lower debt and } \\
\text { higher dividend payout. } \\
\text { Better results for the firms } \\
\text { with more than 50\% change } \\
\text { of previous management. }\end{array}$ \\
\hline $\begin{array}{l}\text { Boubakri, } \\
\text { Cosset } \\
(1998)\end{array}$ & $\begin{array}{l}1980- \\
1992\end{array}$ & $\begin{array}{l}79 \text { firms of } \\
\text { different } \\
\text { sectors, less } \\
\text { developed } \\
\text { countries } \\
\text { (Brazil, Chile, } \\
\text { Mexico, } \\
\text { Turkey, } \\
\text { Portugal, etc.). }\end{array}$ & $\begin{array}{l}\text { Firm performance } \\
\text { before and after } \\
\text { the privatization } \\
\text { (profitability, LP, } \\
\text { investments, } \\
\text { output, } \\
\text { employment). }\end{array}$ & $\begin{array}{l}\text { After the privatization } \\
\text { significant growth of } \\
\text { profitability, LP, } \\
\text { investments, real output, } \\
\text { employment, and dividend } \\
\text { payout. Better results for } \\
\text { countries with higher } \\
\text { economic level, and firms } \\
\text { without state control share. }\end{array}$ \\
\hline $\begin{array}{l}\text { La Porta, } \\
\text { López-de- } \\
\text { Silanes } \\
\text { (1999) }\end{array}$ & $\begin{array}{l}1983- \\
1991\end{array}$ & $\begin{array}{l}218 \text { non- } \\
\text { financial } \\
\text { corporations } \\
\text { of different } \\
\text { sectors } \\
\text { (Mexico). }\end{array}$ & $\begin{array}{l}\text { Firm performance } \\
\text { before and after } \\
\text { the privatization } \\
\text { (profitability, LP, } \\
\text { employment, } \\
\text { wages). }\end{array}$ & $\begin{array}{l}\text { After the privatization } \\
\text { significant growth of } \\
\text { profitability, LP, and total } \\
\text { productivity. Employment } \\
\text { decreases to 50\% but wages } \\
\text { arise. }\end{array}$ \\
\hline
\end{tabular}




\begin{tabular}{|l|l|l|l|l|}
\hline $\begin{array}{l}\text { Dewenter, } \\
\text { Malatesta } \\
(2001)\end{array}$ & $\begin{array}{l}1975, \\
1985,\end{array}$ & $\begin{array}{l}\text { 500 of the } \\
\text { biggest } \\
\text { international } \\
\text { firms with } \\
\text { different type } \\
\text { of ownership } \\
\text { (total 1,369 } \\
\text { observations) }\end{array}$ & $\begin{array}{l}\text { Impact of } \\
\text { ownership } \\
\text { structure on firm } \\
\text { performance } \\
\text { (profitability, LP, } \\
\text { debt). }\end{array}$ & $\begin{array}{l}\text { Compared to stat-owned } \\
\text { firms, private firms are } \\
\text { significantly more profitable } \\
\text { (twice) with lower debt and } \\
\text { higher LP. Growth of } \\
\text { profitability is the most } \\
\text { significant during 3 years } \\
\text { after the privatization. }\end{array}$ \\
\hline $\begin{array}{l}\text { Boubakri, } \\
\text { Cosset }\end{array}$ & $1989-$ & $\begin{array}{l}\text { 16 African } \\
\text { firms } \\
\text { (Morocco, } \\
\text { Nigeria, } \\
\text { Tunisia, } \\
\text { Ghana, } \\
\text { Senegal) }\end{array}$ & $\begin{array}{l}\text { Firm performance } \\
\text { before and after } \\
\text { the privatization } \\
\text { (profitability, } \\
\text { sales, } \\
\text { investments). }\end{array}$ & $\begin{array}{l}\text { After the privatization } \\
\text { growth of profitability but } \\
\text { not significant, decrease of } \\
\text { efficiency and real sales } \\
\text { (also not significant). } \\
\text { Growth of investments is } \\
\text { statistically significant. }\end{array}$ \\
\hline
\end{tabular}

Note: $L P=$ labour productivity;

Source: own survey

\subsection{Empirical Studies on Transition Economies}

The real boom in empirical studies examining the effects of privatization on the enterprise performance was recorded in the 1990s as a reaction to the collapse of centrally planned economies in socialist countries and the subsequent privatization, whose scope is unprecedented in history. Transition economies are characterized by simultaneous actions of a large number of both state and privatized enterprises operating under similar conditions, which allows to compare the results and to analyze the influence of type of ownership on the enterprise performance. Frydman et al. (1999) note that transformation environment is characterized by a high degree of uncertainty and deep institutional changes. Under this condition, behavior in compliance with standard rules gives a relatively weak competitive advantage.

Havrylyshyn and McGettingan (1999) select several usual topics of studies on privatization of enterprises in transition economies related to the rate and extent of privatization, conditions of privatization program, or type of new management (principal-agent problem). They consider whether it was better to close state firms down and start a new private business, or to privatize formerly state-owned enterprises. Excited transformation debate took place between supporters of rapid privatization process (shock therapy) and defenders of gradual transition. Other issues were connected with the fact whether enterprises should be privatized into the hands of the original managers or employees (insiders), rather than outside domestic or foreign investors (insiders). As noted by Olson (2000), with collapse of communism, central governments lost much of their power which was often transferred to the existing management and workers who were the main groups organized for collective action. But in many large state-owned companies selected for privatization, management and workers were not fans of outsider privatization due to fear of structural changes and 
competitive markets. Therefore, the firms were given mainly to insiders (especially in Russia and other post-Soviet countries) who connected their lobbying power with other groups that were not inclined to economic reform. It often resulted in insufficient restructuring of enterprises and privatization losses.

The problem of early studies of privatization in transition economies was a short time since privatization to evaluation of the effects of transformation, including privatization. According to the studies from the first years of transformation, privatization appeared to be non-essential for transformation and restructuring of enterprises to improve their economic performance. As described in study by Carlin, Reenen and Wolf (1995) who were examining 450 firms in Czechoslovakia, Hungary, Poland, and Russia in the period 1990-1993, it is not more probable that the privatized enterprises go through the efficient restructuring, including growth of their performance, compared with the stateowned enterprises. Likewise, Pinto, Belka and Krajewski (1993) point out that number of Polish state-owned companies started reforms towards increasing the efficiency of production at the very beginning of the transformation without being privatized at first. But this view was later challenged; other studies have shown that privatization is associated with a certain degree of increase in corporate performance in transition economies, regardless of the background of the competitive environment. These following studies thus provide findings consistent with the previous research in developing countries and developed economies; the privatization generally leads to increase in the enterprise performance.

Literature dealing with the privatization of the 1990s primarily focuses on Central Europe and the Baltic states because the process of liberalization and privatization started here at first. ${ }^{7}$ Moreover, these countries first tried to achieve and finally joined the EU. Compared to the countries of Central and Eastern Europe, initial conditions of the post-Soviet countries were rather specific. The transformation in the post-Soviet republics came after decades of struggle with a rigid and centralized power of Moscow; besides, some countries suffered from a civil war or military conflict over the border. Countries of the Former Soviet Union were much more integrated and centralized in both the production sources and trade. Central Moscow authorities fully controlled cooperation between enterprises across Soviet republics, moreover, all foreign trade was in the hands of Moscow. Managers of the Soviet enterprises were not interested in marketability of products to foreign countries, in meeting of international standards and making business contacts with foreign partners.

As described by Hoss and Stiglitz (2002), after privatization in Russia had started, it was expected that privatization process itself would create a strong demand for quality legal environment that would promote effective functioning of a market economy. Similarly, Czech authors of the privatization methods hypothesized that privatization

\footnotetext{
${ }^{7}$ We can hardly find a study dealing with the impact of privatization on the enterprises in the Former Soviet Union and other European countries outside the EU, such as Albania and other Balkan countries. Sachs, Zinnes, and Eilat (2000) explain that it is, for one thing, due to high price of a data sample from business sector in these countries, and for another, due to low comparability of data which is collected by different method, particularly during the transformation process.
} 
and reforms themselves would create pressure on establishment of legal institutions based on market demand. That did not happen, though. On the contrary, the legal uncertainty of the institutional environment facilitated the activities leading to rapid acquisition of property, and therefore to tunneling of privatized companies, which was sometimes the main intention of privatizers. So it is not surprising that an alienation of company property was widespread; this is true both for countries of Central and Eastern Europe and the Former Soviet Union. Without effective supervision over new owners (previous member of staff, managers and external investors), enterprises had to face destruction rather than restructuralisation.

\section{Empirical Studies on Transition Economies: Central and Eastern Europe}

A comparative study of the World Bank (Pohl et al. 1997) which analyzes a sample of more than 6,300 industrial enterprises in seven countries (Bulgaria, the Czech and Slovak Republic, Hungary, Poland, Romania, and Slovenia) in the period 1992-1995 is one of the greatest works in a number of surveyed companies. The sample is compiled in such a way that the selected enterprises present a large percentage of employees in industry. ${ }^{8}$ All companies had been originally state-owned, then some of them were privatized $^{9}$, and some remained in state hands. The study analyzes profitability of enterprises, cash flows, growth in labour productivity, total productivity growth and export growth, and compare the extent of restructuring of enterprises, including other factors affecting the restructuring (influence of privatization speed, concentration of ownership, regulation of wage growth, financial discipline of government and banks, etc.). As a measure of restructuring, the authors use total productivity growth (output growth to input growth).

In five controlled countries (the Czech and Slovak Republic, Hungary, Poland, and Slovenia), there is significant growth of firm profitability in the period 1992-1995, and there is only low growth of profitability in the case of Romanian and Bulgarian enterprises. The study shows that success of restructuring (i.e. increase in profitability) is essentially affected by change of ownership from state to private hands. Successfully privatized firms increase the total productivity more of around 13\% (whilst state-owned enterprises only of around 3\%). Labour productivity of the privatized firms also increases, and the increase is moreover higher than growth of real wages, although wages increase relatively fast. Situation in state-owned firms is the opposite: they show decrease of labor productivity. Privatized firms are also more successful in investments per worker (8 times higher than in the state-owned firms).

Frydman et al. (1997; 1999) focus on middle industrial enterprises of different sectors in the Czech Republic, Poland, and Hungary, and analyze impact of the initial phase of privatization (1990-1994) on the firm performance. The authors note that all firms had to reduce the excessive employment inherited from the past, all had to look for new markets, and had to improve their poor products and reduce wasting of energy and material resources. Compared to the state-owned firms, the privatized enterprises are able to restructure definitely more efficiently despite having faced large decline of returns at the beginning of transformation. According to an econometric analysis,

\footnotetext{
${ }^{8}$ The selected firms cover $41-93 \%$ of employment in industrial sectors in a certain country.

${ }^{9}$ According to Pohl et al., enterprises with more than $30 \%$ share of private ownership are considered to be privatized.
} 
private ownership significantly increases the enterprise performance regardless of the industry or country, and even generates significant growth of employment. Companies privatized by outsiders have better results than those privatized by insiders, among which firms owned by employees are significantly less efficient; this type of privatization even decreases labour productivity and increases costs, unlike the other privatized firms.

Among the countries of Central and Eastern Europe, a number of microeconomic analyses deal directly with the Czech Republic. Claessens, Djankov, and Pohl (1997) examine impact of privatization on performance of 706 Czech privatized enterprises in the period 1992-1995. The authors conclude that privatized firms are more efficient, as measured by higher profitability and higher market value. More concentrated ownership increases performance of companies. Harper (2002) also deals with Czech privatized enterprises (453 firms from industry and services in the period 1992-1994), and examines their performance 2 years before and 2 years after the privatization, which is measured as labour productivity (real returns and real net revenue per employee), profitability and real returns. Despite the study by Frydman et al., which is mentioned above, Harper concludes that the privatized firms significantly decrease a number of employees, and even decline the real output. Different results are also in the case of concentration of ownership, which seems to be insignificant. The same conclusion is obvious in the case of performance: private ownership is connected with higher performance. Like other authors, Harper too underlines the importance of economic and political institutions, which is appeared to be essential for success of privatization. The more stable and more developed financial and economic market, the higher benefits from the privatization are.

As described in the study of Czech economists Hanousek, Kocenda and Svejnar (2004, 2006) who were examining at first around 900 Czech enterprises privatized by 1995 , reduction of the state share itself does not automatically lead to an increase in efficiency because it depends on type of privatizer. In the case of financial groups and individual privatizers, study does not demonstrate higher performance of companies, unlike other outsiders, e.g. foreign investors, who increase the performance of privatized firms. In order to determine the effect of ownership structure and ownership concentration on profitability in the period 1996-1999, the same authors analyze a sample of 1,500 medium and large enterprises. The authors tend to the fact that some private ownership structures enhance the dynamics of post-privatization performance, compared with public ownership and domestic investors, foreign investors are more successful in increasing the profitability.

Table 2 summarizes the results of the studies that examine impact of ownership on enterprises in transition economies of Central and Easter Europe. We find out that private ownership brings a significant increase in firm performance. According to the studies, outsiders (i.e. privatizers beyond the original structure of the company) are more successful, especially foreign investors. Among the insiders, we can see the worst results in the case of employee ownership. As described in Frydman et al. (1997, 1999), employee ownership results in a decrease in labour productivity and an increase in the costs. Presented studies suggest that higher concentration of ownership leads to higher performance of enterprises, and similarly as in the case of the studies of non-transitive 
economies, the conclusions from the transition countries are not clear in what impact privatization has on employment in privatized firms.

Table 2: Impact of Ownership on Enterprise Performance: Transition Economies of Central and Eastern Europe

\begin{tabular}{|c|c|c|c|c|}
\hline Authors & Period & Sample & Research goal & Conclusions \\
\hline $\begin{array}{l}\text { Claessens, } \\
\text { Djankov, } \\
\text { Pohl } \\
(1997)\end{array}$ & $\begin{array}{l}1992- \\
1995\end{array}$ & $\begin{array}{l}706 \text { Czech } \\
\text { privatized } \\
\text { firms }\end{array}$ & $\begin{array}{l}\text { Impact of the } \\
\text { privatization } \\
\text { on firm } \\
\text { performance } \\
\text { (profitability, } \\
\text { market value } \\
\text { of the firm). }\end{array}$ & $\begin{array}{l}\text { Privatized firms are more } \\
\text { efficient; the higher } \\
\text { ownership concentration, } \\
\text { the higher profitability and } \\
\text { market value. }\end{array}$ \\
\hline $\begin{array}{l}\text { Pohl, } \\
\text { Anderson, } \\
\text { Claessens, } \\
\text { Djankov } \\
(1997)\end{array}$ & $\begin{array}{l}1992- \\
1995\end{array}$ & $\begin{array}{l}6,300 \\
\text { privatized } \\
\text { and state- } \\
\text { owned } \\
\text { industrial } \\
\text { firms; } \\
\text { Visegrad } \\
\text { countries, } \\
\text { Bulgaria, } \\
\text { Romania, } \\
\text { Slovenia. }\end{array}$ & $\begin{array}{l}\text { Impact of the } \\
\text { restructuring } \\
\text { (privatization } \\
\text { speed, } \\
\text { concentration } \\
\text { of ownership, } \\
\text { etc.) on firm } \\
\text { performance } \\
\text { (profitability, } \\
\text { LP, growth of } \\
\text { total } \\
\text { productivity, } \\
\text { export, etc.). }\end{array}$ & $\begin{array}{l}\text { Essential impact of } \\
\text { privatization on the growth } \\
\text { of total productivity (an } \\
\text { average of } 4.5 \% \text { per annum, } \\
4 \text { times faster than in state } \\
\text { enterprises). Growth of LP } \\
\text { in privatized firms of } 7.2 \% \text {; } \\
\text { decrease of } 0.3 \% \text { in state- } \\
\text { owned firms. } 70-90 \% \text { of LP } \\
\text { growth is ascribed to the } \\
\text { impact of privatization. } \\
\text { Investments per workers } 8 \\
\text { times higher in privatized } \\
\text { firms than in state-owned } \\
\text { ones. }\end{array}$ \\
\hline $\begin{array}{l}\text { Frydman, } \\
\text { Gray, } \\
\text { Hessel, } \\
\text { Rapaczynski } \\
(1997 ; \\
1999)\end{array}$ & $\begin{array}{l}1990- \\
1994\end{array}$ & $\begin{array}{l}\text { Originally } \\
500, \text { after } \\
\text { elimination } \\
\text { around } 200 \\
\text { private and } \\
\text { state-owned } \\
\text { industrial } \\
\text { firms; } \\
\text { The Czech } \\
\text { R., Poland, } \\
\text { Hungary }\end{array}$ & $\begin{array}{l}\text { Impact of } \\
\text { ownership } \\
\text { structure on } \\
\text { firm } \\
\text { performance } \\
\text { (growth of } \\
\text { returns, } \\
\text { employment, } \\
\text { LP, costs). }\end{array}$ & $\begin{array}{l}\text { Private ownership } \\
\text { significantly increases } \\
\text { performance, regardless to } \\
\text { certain country and industry. } \\
\text { Better results in the case of } \\
\text { outsiders (growth of returns } \\
\text { and productivity around of } \\
10 \% \text { annually without } \\
\text { significant negative impact } \\
\text { on employment). Employee } \\
\text { ownership has the worst } \\
\text { results among insider } \\
\text { privatizers: decrease in LP, } \\
\text { increase in costs. }\end{array}$ \\
\hline
\end{tabular}




\begin{tabular}{|c|c|c|c|c|}
\hline $\begin{array}{l}\text { Harper } \\
(2002)\end{array}$ & $\begin{array}{l}1990- \\
1996\end{array}$ & $\begin{array}{l}453 \\
\text { privatized } \\
\text { firms of } \\
\text { different } \\
\text { industries, } \\
\text { The Czech } \\
\text { Republic. }\end{array}$ & $\begin{array}{l}\text { Firm } \\
\text { performance } \\
\text { before and } \\
\text { after the } \\
\text { privatization } \\
\text { (employment, } \\
\text { LP, } \\
\text { profitability). }\end{array}$ & $\begin{array}{l}\text { The privatized firms: } \\
\text { significant decrease in a } \\
\text { number of employees and } \\
\text { real output, but increase in } \\
\text { performance. The first wave } \\
\text { of privatization had worse } \\
\text { results than the second one. }\end{array}$ \\
\hline $\begin{array}{l}\text { Hanousek, } \\
\text { Kočenda, } \\
\text { Švejnar } \\
(2004)\end{array}$ & $\begin{array}{l}1996- \\
1999\end{array}$ & $\begin{array}{l}1,500 \text { middle } \\
\text { and large } \\
\text { firms after } \\
\text { large-scale } \\
\text { privatization } \\
\text { The Czech } \\
\text { Republic }\end{array}$ & $\begin{array}{l}\text { Impact of } \\
\text { ownership } \\
\text { structure and } \\
\text { concentration } \\
\text { on firm } \\
\text { performance. }\end{array}$ & $\begin{array}{l}\text { Some private ownership } \\
\text { structures increase dynamics } \\
\text { of post-privatization } \\
\text { performance: compared to } \\
\text { the state ownership and } \\
\text { domestic privatizers, better } \\
\text { results in the case of } \\
\text { concentrated foreign } \\
\text { ownership. }\end{array}$ \\
\hline $\begin{array}{l}\text { Hanousek, } \\
\text { Kočenda, } \\
\text { Švejnar } \\
(2006)\end{array}$ & $\begin{array}{l}1990- \\
1996\end{array}$ & $\begin{array}{l}\text { Around } 900 \\
\text { privatized } \\
\text { firms till } \\
\text { 1995; } \\
\text { The Czech } \\
\text { R. }\end{array}$ & $\begin{array}{l}\text { Impact of the } \\
\text { privatization } \\
\text { on } \\
\text { performance } \\
\text { (cost- } \\
\text { effectiveness, } \\
\text { profitability). }\end{array}$ & $\begin{array}{l}\text { Only decrease in state share } \\
\text { itself does not lead to } \\
\text { increase in performance. } \\
\text { Financial groups and } \\
\text { individuals as new owners } \\
\text { do not increase } \\
\text { performance, other outsiders } \\
\text { have better results. }\end{array}$ \\
\hline
\end{tabular}

Note: $L P$ = labour productivity; Insider = privatizer from among the original managers or employees; outsider = privatizer from outside the enterprise structure (individual investors, investment funds, financial institutions, domestic firms, and foreign investors).

Source: own survey

\section{Empirical Studies on the Transition Economies: the Former Soviet Union}

Privatization in post-Soviet countries is characterized by dominant role of employees and important role of the state. As described in Earle (1998), defenders of employee privatization were convinced that this reduced the principal-agent problem. This opinion claims that employee privatization protects from asymmetric information and encourages motivation of employees on the firm results and increase in productivity where it is possible. Perevalov, Gimady, and Dobrodey (1999) also give reasons for the employee or manager privatization in Russia: they say that insiders have better access to information about a real value of privatized enterprises. Furthermore, supporters of the employee privatization point that outsiders are handicapped in an environment where it is difficult to enforce contracts and agreements because legal institutional environment was not very favourable and distrustful of privatizers from outside of the original enterprise structure. Moreover, transfer of firms to insiders was supported directly by the state to keep great power over the privatized company. It was very difficult for outsiders to press for needed changes against original management and employees. 
At the beginning of the transformation, policy-makers and analysts in post-Soviet countries assumed that the privatizers from among employees would sell their shares in the enterprises to other investors with the necessary capital, new technologies, and access to new markets. After all, it did not happen. One of the reasons was that workers' desire to keep control of the company prevailed because of traditional solidarity among employees and poor functioning of the capital market. Insufficient institutional environment and the whole business climate not supporting restructuring caused slow process of transformation. On the basis of his study of Georgian firms, Djankov (1999) claims that despite its positive privatization effect, enterprise privatization could not overcome burden of the past and inappropriate conditions. In the adverse business environment with lack of responsible managers, there are not such big differences between the private and the state-owned enterprises as in the case of the Central European countries where the transformation nevertheless proceeded faster, although with a number of difficulties similar to the post-Soviet economies.

Barberis et al. (1996) also point to an adverse influence of existing staff and management structures. They deal with the privatization of Russian state-owned shops known for their inefficiency, sale of poor-quality goods, high stocks, excessive storage space, insufficient services, and short opening hours. Most of the shops needed fast restructuring measured as 4 indicators: rate of renovation of shop, extension of opening hours, changes of suppliers, and reduction of redundant workers. The sample contains $52 \%$ shops privatized by previous managers and employees (dominant type of privatization), $30 \%$ by outsiders and the rest by mixed privatizers. The authors conclude that successful restructuring needs new owners (not original employees and managers) with appropriate skills allowing them manage the store in the market economy and such who are not burdened by ties with both old suppliers and employees. The change of ownership increases probability of restructuring in the case of new management only.

Earle and Estrin (1998) analyze Russian industrial enterprises to determine whether privatization, competition forces and hard budget constraint increase efficiency of firms. The authors present robust proofs of the positive impact of private ownership on labour productivity: $10 \%$ increase in share of private ownership leads to $3-5 \%$ real growth of labour productivity. Influence of competition is weaker, depending on the measurement and model specification. State support in the form of various subsidies of ailing enterprises is negatively reflected in the rate of privatization (although this influence is not a more significant one). Another similar study by Earle (1998) based on a sample of 300 enterprises proves a statistically significant impact of private ownership (compared to state ownership) on increase in labor productivity in the case of managerial and employee privatizers, and individual outsiders. Other types of privatization (investment funds, foreign investors) do not prove positive impact on increase in enterprise performance.

Similar results (positive impact of privatization on labour productivity) are proved by Djankov (1999) who examines relationship between ownership structure and restructuring of firms on a sample of 960 privatized industrial enterprises in 6 postSoviet republics (Georgia, Kazakhstan, Kyrgyzstan, Moldova, Russia, and Ukraine) in the period 1995-1997. The study does not include the Baltic States and six other former Soviet republics due to inaccessibility of credible data. The restructuring is measured as the growth of labor productivity, and improvement of working conditions of employees. 
The author concludes that the observed privatized firms achieve an increase in labour productivity (annually average growth of 13\%) which is higher than in the transition economies of Central Europe (7\% average growth). In the case of state-owned firms, we can see lower rate of restructuring and even decline in the labor productivity.

Grygorenko and Lutz (2004) also confirm the positive impact of private ownership on the firm productivity. The authors examine a sample of 466 Ukraine joint-stock companies; some of them state-owned and the others after privatization during the period 1997-1999. Based on the results, majority state ownership indicates significantly worse performance whereas private ownership (although not a 100\% one) increases performance, mostly in the years immediately after privatization. Although the firms with majority private ownership prosper significantly better than the others, a certain percentage of the state share improves firm performance, compared with $100 \%$ private ownership. The explanation of the authors is that these companies continue to benefit from connection to the state support, compared to the firms without any state subsidies.

Contrary to previous papers, Perevalov, Gimady, and Dobrodey (1999) present rather worse results in favor of private ownership. To determine impact of privatization on firm performance, they examine a sample of 198 industrial enterprises of Sverdlovsk region ${ }^{10}$ in the period 1992-1996. They use panel regression and compare the firm performance (real returns, profitability, costs, and labour productivity) before and after privatization. The authors conclude that privatization itself does not lead to an overall performance growth; the positive impact is confirmed only in the case of operating profit and to some extent in labour productivity, too.

Table 3 summarizes results of the studies on the impact of private and state ownership on firm performance in the post-Soviet republics. We can conclude that transformation from state to private ownership has generally statistically significant effect on the labor productivity growth. Regarding the type of privatization process (outsiders vs. insiders), the results are not so straightforward. However, all researchers examining the impact of ownership on the post-Soviet firm performance agree that the transformation was influenced by unsatisfactory quality of the institutional environment including insufficient protection of property rights, excessive influence of the state in partially privatized firms, inadequate supervision of the financial market, and dysfunctional market shares. Due to a burden of the past, lack of experience with free market economy and with private ownership of production factors, due to lack of the functioning formal and informal rules, we can observe that privatizers were recruited from investors without long-term goals, mostly at the expense of sustainable prosperity.

\footnotetext{
${ }^{10}$ The sample covers $29 \%$ of all privatized firms in the Sverdlovsk region where process of privatization was much faster than in other part of Russia. In 1995, there were only $7.5 \%$ of industrial enterprises in state ownership.
} 
Table 3: Impact of Ownership on Enterprise Performance: Transition Economies of the post-Soviet countries

\begin{tabular}{|c|c|c|c|c|}
\hline Authors & Period & Sample & Research goal & Conclusions \\
\hline $\begin{array}{l}\text { Barberis, } \\
\text { Boycko, } \\
\text { Shleifer, } \\
\text { Tsukanova } \\
(1996)\end{array}$ & $\begin{array}{l}1992- \\
1993\end{array}$ & $\begin{array}{l}452 \text { stores, } \\
\text { most of them } \\
\text { privatized; } \\
\text { Russia }\end{array}$ & $\begin{array}{l}\text { Impact of } \\
\text { ownership } \\
\text { structure on } \\
\text { restructuring } \\
\text { (high } \\
\text { performance) of } \\
\text { stores. }\end{array}$ & $\begin{array}{l}\text { Privatization by original } \\
\text { employees or managers } \\
\text { does not lead to the higher } \\
\text { probability of restructuring, } \\
\text { only new owner (outsider) } \\
\text { supports higher } \\
\text { performance. }\end{array}$ \\
\hline $\begin{array}{l}\text { Earle, } \\
\text { Estrin } \\
(1998)\end{array}$ & $\begin{array}{l}1990- \\
1994\end{array}$ & $\begin{array}{l}\text { Around } 400 \\
\text { industrial } \\
\text { enterprises } \\
\text { privatized } \\
\text { and state- } \\
\text { owned; } \\
\text { Russia }\end{array}$ & $\begin{array}{l}\text { Firm } \\
\text { performance } \\
\text { before and after } \\
\text { privatization } \\
\text { (real growth of } \\
\text { LP). }\end{array}$ & $\begin{array}{l}\text { Significantly positive } \\
\text { impact of private in } \\
\text { comparison to state } \\
\text { ownership on the real } \\
\text { growth of LP; } 10 \% \text { increase } \\
\text { in share of private } \\
\text { ownership leads to } 3-5 \% \\
\text { growth of LP. State support } \\
\text { (weak budget constrains) } \\
\text { slows rate of restructuring } \\
\text { and higher performance. }\end{array}$ \\
\hline $\begin{array}{l}\text { Djankov } \\
\text { (1999) }\end{array}$ & $\begin{array}{l}1995- \\
1997\end{array}$ & $\begin{array}{l}960 \\
\text { industrial } \\
\text { privatized } \\
\text { enterprises; } \\
\text { Georgia, } \\
\text { Kazakhstan, } \\
\text { Kyrgyzstan, } \\
\text { Moldova, } \\
\text { Russia, and } \\
\text { Ukraine. }\end{array}$ & $\begin{array}{l}\text { Impact of } \\
\text { ownership } \\
\text { structure on } \\
\text { firm } \\
\text { performance } \\
\text { (growth of LP, } \\
\text { improvement of } \\
\text { working } \\
\text { conditions). }\end{array}$ & $\begin{array}{l}\text { Privatized enterprises: LP } \\
\text { growth of } 13 \% \text { per annum; } \\
\text { state and employee } \\
\text { ownership always } \\
\text { associated with decline in } \\
\text { LP (but statistically } \\
\text { insignificant). Foreign } \\
\text { ownership with at least } 30 \% \\
\text { share is statistically } \\
\text { significant associated with } \\
\text { LP growth. }\end{array}$ \\
\hline $\begin{array}{l}\text { Perevalov, } \\
\text { Gimady, } \\
\text { Dobrodey } \\
\text { (1999) }\end{array}$ & $\begin{array}{l}1992- \\
1996\end{array}$ & $\begin{array}{l}198 \text { middle } \\
\text { and large } \\
\text { industrial } \\
\text { privatized } \\
\text { enterprises; } \\
\text { Sverdlovsk } \\
\text { region in } \\
\text { Russia. }\end{array}$ & $\begin{array}{l}\text { Impact of } \\
\text { ownership } \\
\text { structure on } \\
\text { firm } \\
\text { performance } \\
\text { (real growth of } \\
\text { sales, } \\
\text { profitability, } \\
\text { costs, and LP). } \\
\text { Comparison } \\
\text { before and after } \\
\text { privatization. }\end{array}$ & $\begin{array}{l}\text { Privatization itself does not } \\
\text { bring the general growth of } \\
\text { firm performance; only in } \\
\text { some partial cases: positive } \\
\text { impact on operating profit } \\
\text { and LP depending on type } \\
\text { of privatization. } \\
\text { Note: Privatization methods } \\
\text { very heterogeneous; major } \\
\text { part of enterprises privatized } \\
\text { by insiders with certain } \\
\text { share of state. }\end{array}$ \\
\hline
\end{tabular}




\begin{tabular}{|l|l|l|l|l|}
\hline $\begin{array}{l}\text { Grygorenk } \\
\text { o Lutz } \\
(2004)\end{array}$ & $\begin{array}{l}1997- \\
1999\end{array}$ & $\begin{array}{l}466 \\
\text { privatized } \\
\text { and state- } \\
\text { owned join- } \\
\text { stock } \\
\text { companies; }\end{array}$ & $\begin{array}{l}\text { Impact of } \\
\text { ownership } \\
\text { structure on } \\
\text { firm } \\
\text { performance } \\
\text { (real growth of } \\
\text { LP). }\end{array}$ & $\begin{array}{l}\text { Companies with a major } \\
\text { share of state have } \\
\text { significantly worse } \\
\text { performance while private } \\
\text { ownership increases it. }\end{array}$ \\
& Ukraine. & & \\
\hline $\begin{array}{l}\text { Note: LP }=\text { labour productivity; Insider } \\
\text { employees; outsider = privatizer from outside the enterprise structure (individual investors, } \\
\text { investment funds, financial institutions, domestic firms, and foreign investors). }\end{array}$
\end{tabular}

Source: own survey

\section{Conclusion}

This paper presented and analyzed results of empirical studies in order to determine whether private property and privatization of enterprises encourage firms to increase their performance. Firm performance is measured as the growth of profitability, investments, labour productivity, real sales, cost-effectiveness, etc. The survey aimed at two groups of countries: firstly, state-owned and privatized enterprises of non-transition economies until 1990, and secondly, transition economies after the collapse of the socialist systems of central planning economies. The second group of enterprises was divided into two regions: Central and Eastern Europe, and the Former Soviet Union, separately.

The privatization in the last third of the 20th century refers not only to post-socialist bloc of European countries but has become a global phenomenon. Although contemporary Western European countries with market economies and democratic political regimes have been built on the principle of private ownership since the Industrial Revolution, many states have tried to interfere in private property of production factors during the 20th century. Nationalization often resulted only in higher national debt caused by remediation of non-viable enterprises. Finally, in the 1980s, Western countries started privatization process under pressure of the European Union to liberalize markets and to reduce deficits. It is important to note that share of state-owned companies in Western countries was about $10-20 \%$ before the privatization. It is only very small share, compared with the socialist bloc which had to undergo privatization and transformation of tens of thousands of enterprises within a few years. A long time elapsed since the major wave of privatization in Europe and most countries have already completed the transformation process. However, given current nationalization trends, e.g. in Latin America, the results of presented studies may be useful even today.

Theoretical parts of the empirical studies mostly emphasize the positive impact of private property on economic prosperity because it supports efficient use of scarce resources and helps save transaction costs, and so private property contributes to economic welfare of society. Theoretical arguments in favor of privatization of formerly state-owned enterprises are based on the neo-classical assumptions of perfect competition and information, zero transactions costs, and no public goods, without the 
influence of institutional framework including the political and legal institutions, both the formal and the informal rules of game.

Most of the controlled studies use regression analysis and other econometric methods to examine a sample of enterprises by one of two approaches: either comparison of preprivatization to post-privatization performance of the selected privatized firms, or comparison of state-owned firms to private firms at the same time.

Results of the studies examining the impact of ownership on firm performance agree with the fact that private ownership supports performance of enterprises. In the first group of privatized enterprises from non-transition economies, we find statistically significant growth of profitability, labour productivity and investments. As regards employment, two studies present an increase in employment, while another study shows opposite process. Nevertheless, a reduction of the number of workers is associated with growth of wages. According to the study of African privatized firms, the effect of private ownership is not so straightforward due to inappropriate institutional environment without functional financial markets, protection and enforcement of property rights, and the overall institutional stability.

Similar conclusions are confirmed by the results of the second group of enterprises dealing with the impact of privatization on firm performance during the period of transformation. According to the studies focusing on Central and Eastern European countries, we also find out that private ownership brings a significant increase in firm performance (namely labour and total productivity, investments, and profitability). Outsiders (i.e. privatizers from beyond the original structure of the company) are more successful than insiders; we can see the worst results in the case of employee ownership (a decrease in labour productivity and an increase in costs). Similar results related to the positive impact of private ownership on the growth of labour productivity are presented in the studies on the post-Soviet republics. Privatization by insiders (namely employee ownership) seems to be associated with a decline in labour productivity, similarly as in Central and Eastern European economies.

Namely in the case of the post-Soviet countries, the authors of the studies underline the negative influence of poor quality of institutions (insufficient protection of property rights, excessive influence of state in partially privatized firms, etc.) which is the result of the past and changes very slowly. In comparison with other countries passing through the transformation (leaving aside the former country of Yugoslavia, torn and destroyed by civil war), the overall institutional environment of the post-Soviet countries was even more adverse to privatization and total restructuring of the economy than, for example, in the Visegrad countries. Post-Soviet enterprises had to face high transaction costs of conclusion, compliance, and any subsequent enforcement of contracts due to lack of quality legal institutions. Furthermore, there were poorly functioning market of both outputs and inputs, lack of other state institutions for effective supervision of financial institutions (after all, it was not characteristic only for the post-Soviet economy) at that time.

In summary, the results of the studies suggest that private ownership is an important but not sufficient determinant of the long-term firm prosperity subsequently resulted in the overall rise of wealth of nations. The positive impact of private ownership on economic performance can occur only in an appropriate institutional environment with relevant 
legal standards (righteous and enforceable contracts, protection of shareholders and creditors, adequate banking system, functioning bankruptcy courts, capital market supervision, etc.).

\section{References}

BARBERIS, N. et al. (1996). How Does Privatization Work? Evidence from the Russian Shops. Journal of Political Economy, Vol. 104, August 1996, pp. 764-790.

BOARDMAN, A. E., A. R. VINING. (1989). Ownership and Performance in Competitive Environments: A Comparison of the Performance of Private, Mixed, and State-Owned Enterprises. Journal of Law and Economics, Vol. XXXII, April 1989, pp. $1-33$.

BOUBAKRI, N., J. C. COSSET. (1998). The Financial and Operating Performance of Newly Privatized Firms: Evidence from Developing Countries. Journal of Finance, Vol. 53, June 1998, pp. 1081-1110.

BOUBAKRI, N., J. C. COSSET. (2002). Does Privatization Meet the Expectations in Developing Countries? A Survey and Some Evidence from Africa. Journal of African Economies, Vol. 11, February 2002, pp. 111-140.

CARLIN, W., J. V. REENEN, T. WOLFE. (1995). Enterprise Restructuring in Early Transition: The Case of Study Evidence from Central and Eastern Europe. Economics of Transition, Vol. 3, Issue 4, December 1995, pp. 427-458.

CHANG, H., ed. (2007). Institutional change and economic development. New York: United Nations University Press.

CHANG, H., A. SINGH. (1997). Can large firms be run efficiently without being bureaucratic? Journal of International Development, Vol. 9, Issue 6, September 1997, pp. 865-875.

CLAESSENS, S., S. DJANKOV, G. POHL. (1997). Ownership and Corporate Governance: Evidence from the Czech Republic. The World Bank Policy Research Working Paper No. 1737, March 1997.

DEWENTER, K. L., P. H. MALATESTA. (2001). State-Owned and Privately Owned Firms: An Empirical Analysis of Profitability, Leverage, and Labor Intensity. The American Economic Review, Vol. 91, No. 1, March 2001, pp. 320-334.

DJANKOV, S. (1999). Ownership Structure and Enterprise Restructuring in Six Newly Independent States. The World Bank: Policy Research Working Paper 2047, February 1999.

EARLE, J. S. (1998). Post-Privatization Ownership Structure and Productivity in Russian Industrial Enterprises. Stockholm: SITE Working Paper No. 127, March 1998.

EARLE, J. S., S. ESTRIN, 1998. Privatization, Competition and Budget Constrains: Disciplining Enterprises in Russia. Stockholm: SITE Working Paper No. 128, March 1998. 
FRYDMAN, R. et al. (1993). Needed mechanisms of corporate governance and finance in Eastern Europe. Economics of Transition, Vol. I (2), June 1993, pp. 171-207.

FRYDMAN, R. et al. (1997). Private Ownership and Corporate Performance: Some Lessons from Transition Economies. The World Bank Policy Research Working Paper No. 1830, June 1997.

FRYDMAN, R. et al. (1999). When Does Privatization Work? The Impact of Private Ownership on Corporate Performance in the Transition Economies. The Quarterly Journal of Economics, vol. 114, no. 4, November 1999, pp. 1153-1191.

FURUBOTN, E. G., R. RICHTER. (2005). Institutions and Economic Theory: The Contribution of the New Institutional Economics. Michigan: The University of Michigan Press.

GRYGORENKO, G., S. LUTZ. (2004). Firm Performance and Privatization in Ukraine. Bonn: Zentrum für Europäische Intergrationsforschung, Working Paper B0427, October 2004.

HANOUSEK, J., E. KOČENDA, J. ŠVEJNAR. (2004). Ownership, Control and Corporate Performance after Large-Scale Privatization. William Davidson Institute Working Paper, No. 652, February 2004.

HANOUSEK, J., E. KOČENDA, J. ŠVEJNAR. (2006). Rozdělení, privatizace podniků a jejich výkonnost. Politická ekonomie, 4, 2006, pp. 467-489.

HARPER, J. T. (2002). The Performance of Privatized Firms in the Czech Republic. Journal of Banking \& Finance, Vol. 26, Issue 4, April 2002, pp. 621-649.

HAVRYLYSHYN, O., D. McGETTIGAN. (1999). Privatization in Transition Countries: A Sampling of the Literature. IMF Working Paper, January 1999.

HEITGER, B. (2004). Property Rights and Wealth of Nations: A Cross-country study. Cato Journal, vol. 23, no. 3, winter 2004, pp. 381-402.

JÜTTING, J. (2003) Institutions and Development: a Critical Review. OECD, Development Center.

KARPOFF, J. M. (2001). Public versus Private Initiative in Arctic Exploration: The Effects of Incentives and Organizational Structure. Journal of Political Economy, Vol. 109, No. 1, February 2001, pp. 38-78.

KLUSOŇ, V. (2004). Instituce a odpovědnost. K filozofii ekonomické vědy. Praha: UK Karolinum.

KOUBA, K., O. VYCHODIL, J. ROBERTS. (2005). Privatizace bez kapitálu. Zvýšené transakční náklady české transformace. Praha: Karolinum.

LA PORTA, R., F. LÓPEZ-DE-SILANES. (1999). The Benefits of Privatization: Evidence from Mexico. Quarterly Journal of Economics, Vol. 114, No. 4, November 1999, pp. 1193-1242.

MEGGINSON, W. L., R. C. NASH, M. van RANDENBORGH. (1994). The Financial and Operating Performance of Newly Privatized Firms: An International Empirical Analysis. The Journal of Finance, Vol. XLIX, No. 2, June 1994, pp. 403-452. 
MERCURO, N., S. G. MEDEMA. (2006). Economics and the Law: from Posner to Postmodernism and Beyond. Princeton: Princeton University Press.

NORTH, D. C. (1990). Institutions, Institutional Change and Economic Performance. Cambridge: Cambridge University Press.

OLSON, M. (1996). Big Bills Left on the Sidewalk: Why Some Nations are Rich, and Others Poor. Journal of Economic Perspectives, vol. 10/1996, pp. 3-24.

OLSON, M. (2000). Power and Prosperity: Outgrowing Communist and Capitalist Dictatorships. New York: Basic Books.

PEREVALOV, Y., I. GIMADY, V. DOBRODEY. (1999). Impact of Privatization on Performance of Industrial Enterprises in Russia. In: The First Conference of the Global Development Network: „GDN-99: Bridging Knowledge and Policy“. Bonn, December 1999.

PINTO, B., M. BELKA, S. KRAJEWSKI. (1993). Transforming State Enterprises in Poland: Evidence on Adjustment by Manufacturing Firms. Brookings Papers on Economic Activity, No. 1, pp. 213-270.

POHL, G. et al. (1997). Privatization and Restructuring in Central and Eastern Europe: Evidence and Policy Options. World Bank Technical Paper No. 368, May 1997.

SACHS, J., C. ZINNES, Y. EILAT. (2000). The Gains from Privatization in Transition Economies: Is „Change of Ownership “Enough? Cambridge: Harvard Institute for International Development. CAER II Discussion Paper 63, February 2000.

SHIRLEY, M., P. WALSH. (2000). Public versus Private Ownership: The Current State of the Debate. World Bank Policy Research Working Paper 2420, August 2000.

SOTO, H. de. (2003). The Mystery of Capital: Why Capitalism Triumphs in the West and Fails Everywhere Else. New York: Basic Books.

ZAK, P. J. (2002). Institutions, Property Rights, and Growth. Recherches économiques de Louvain, Vol. 68/2002, pp. 55-73. 